\title{
Digestible Carbohydrate - an Independent Effect on Diabetic Control in Type 2 (Non-Insulin-Dependent) Diabetic Patients?
}

\author{
H.C. R. Simpson, R. D. Carter, S. Lousley, and J. I. Mann \\ Diabetes Research Laboratories and Department of Community Medicine and General Practice, Radcliffe Infirmary, Oxford, UK
}

\begin{abstract}
Summary. Many studies have shown high carbohydrate, high fibre diets to benefit diabetic control, the improvement being attributed mainly to an effect of fibre. This study investigated the possible beneficial effects of the digestible carbohydrate component. A diet rich in carbohydrate was compared with a traditional low carbohydrate diet in 10 Type 2 (non-insulin-dependent) diabetic patients, using a crossover design; both diets contained $<20 \mathrm{~g}$ dietary fibre/day. During 24-h metabolic profiles carried out after 4 weeks on each diet, the mean basal plasma glucose (mean of $03.00,05.00$ and $07.00 \mathrm{~h}$ values) was $5.3 \mathrm{mmol} / 1$ on the high carbohydrate diet and $5.9 \mathrm{mmol} / 1$ on the low carbohydrate diet $(p<0.05)$, despite the 2-h postprandial glucose (mean of three main meals) being higher on the high carbohydrate diet than on the low carbohydrate diet ( 8.7 versus $7.3 \mathrm{mmol} / 1, p<0.01$ ). Overall diabetic control was
\end{abstract}

the same throughout the study, as judged by a mean $24-\mathrm{h}$ plasma glucose of $6.7 \mathrm{mmol} / 1$ on the high carbohydrate and $6.6 \mathrm{mmol} / \mathrm{l}$ on the low carbohydrate diet, and haemoglobin $\mathrm{A}_{1 \mathrm{c}}$ percentage of 8.3 on both diets. Mean cholesterol was $4.55 \mathrm{mmol} / 1$ on both diets and fasting plasma triglyceride was $2.83 \mathrm{mmol} / 1$ on the high carbohydrate and $2.55 \mathrm{mmol} / 1$ on the low carbohydrate diet $(p=\mathrm{NS})$. These results indicate that a diet rich in carbohydrate, but restricted in fibre, does not cause overall deterioration of diabetic control or lipid metabolism in stable Type 2 diabetic patients, and suggest that digestible carbohydrate has an effect on basal blood glucose independent of fibre.

Key words: Diabetic diet, Type 2 diabetes, carbohydrates, dietary carbohydrates.
A high carbohydrate, high fibre intake improves blood glucose control in both Type 1 (insulin-dependent) [1-3] and Type 2 (non-insulin-dependent) [3, 4] diabetic patients. Delayed absorption [5, 6], alteration of gut hormones [7] and an effect on insulin receptors [8] have all been suggested as mechanisms. Several studies have demonstrated an improvement in some aspect of diabetic control when fibre intake was increased but digestible carbohydrate content held constant $[2,5,9,10]$. One study, using a liquid formula diet, showed significant reduction of fasting glucose levels when carbohydrate intake was increased [11]. No study, however, has distinguished between the effects of fibre and those of digestible carbohydrate. We have given a diet rich in digestible carbohydrate but low in fibre to a group of Type 2 diabetic patients, to determine whether carbohydrate has an effect on blood glucose separate from that of fibre.

\section{Patients and Methods}

\section{Patients}

Ten Type 2 diabetic patients (aged 45-68 years, mean 58 years), were recruited from the Diabetic Clinic, Oxford. Three patients had mild background retinopathy on fundoscopy, but none had proliferative changes. Plasma urea and creatinine levels were within normal limits in all subjects. Evidence of neuropathy was limited to loss of ankle vibration sense and ankle deep tendon reflexes. Eight were on sulphonylurea drugs (four on glibenclamide, three on chlorpropamide and one on tolbutamide) and two were treated by diet alone. Mean duration of diabetes was 6 years (range 1-15 years). Mean percentage of ideal body weight was $119 \%$ (range $98 \%-148 \%$ ). There were eight males and two females. All had a plasma glucose $>10 \mathrm{mmol} / \mathrm{l}$ when they first developed diabetes. Informed consent to participation in the study was obtained from all subjects.

\section{Diets}

The control diet was a standard diabetic diet, similar to that still consumed by most patients with Type 2 diabetes throughout the UK. Approximately $35 \%$ of calories were taken as carbohydrate, mainly in complex form, $45 \%$ as fat and $20 \%$ as protein (Table 1 ). Mean total dietary fibre intake of the ten patients was $14.3 \mathrm{~g} / 24 \mathrm{~h}$.

The high carbohydrate diet comprised $60 \%$ of total calories as carbohydrate, again with simple sugars restricted, the remainder being $20 \%$ as fat and $20 \%$ as protein. Despite the high intake of complex carbohydrate, mean fibre intake was still only $16.8 \mathrm{~g} / 24 \mathrm{~h}$. This was achieved by giving much of the carbohydrate as white bread.

\section{Experimental Design}

For at least 2 weeks, overall control of the patients was studied and any appropriate changes made to their treatment. When control was 
judged to be as good as possible, they were randomised to start either the high or low carbohydrate diet. After 4 weeks, all were admitted to hospital for a $24-\mathrm{h}$ metabolic profile, during which blood samples were taken through an indwelling forearm cannula at approximately hourly intervals for measurement of plasma glucose and insulin. Samples were taken ten times during the profile to measure plasma total cholesterol and lipoprotein fractions and plasma triglycerides. A fasting sample was taken for percentage of glycosylated haemoglobin $\left(\mathrm{Hb}_{1 \mathrm{c}}\right)$ estimation. Patients were then discharged home to start the alternative diet, and readmitted 4 weeks later for a second similar profile. Corresponding meals during the two profiles were isocaloric and taken at the

Table 1. Mean percentage of total calories provided by basic food constituents and mean daily dietary fibre intake on high carbohydrate and low carbohydrate diets

\begin{tabular}{|c|c|c|c|c|}
\hline Diet & $\begin{array}{l}\text { Carbo- } \\
\text { hydrate } \\
(\%)\end{array}$ & $\begin{array}{l}\text { Fat } \\
(\%)\end{array}$ & $\begin{array}{l}\text { Protein } \\
(\%)\end{array}$ & $\begin{array}{l}\text { Total dietary } \\
\text { fibre } \\
(\mathrm{g} / 24 \mathrm{~h})\end{array}$ \\
\hline High carbohydrate & 60 & 22 & 18 & 16.8 \\
\hline Low carbohydrate & 35 & 47 & 18 & 14.3 \\
\hline
\end{tabular}

Details of the diets used in this study can be obtained from the authors on request

Table 2. Various measures of diabetic control during profiles on the two diets

\begin{tabular}{llll}
\hline Index & $\begin{array}{l}\text { Low } \\
\text { carbohydrate }\end{array}$ & $\begin{array}{l}\text { High } \\
\text { carbohydrate }\end{array}$ & $p$ \\
\hline Blood glucose $(\mathrm{mmol} / \mathrm{l})$ & & & \\
Basal $^{\mathrm{a}}$ & $5.9 \pm 1.6$ & $5.3 \pm 0.9$ & $<0.05$ \\
2 h Post-prandial $^{\mathrm{b}}$ & $7.3 \pm 1.6$ & $8.7 \pm 2.1$ & $<0.01$ \\
Incremental $^{\mathrm{c}}$ & $1.4 \pm 0.7$ & $2.8 \pm 1.2$ & $<0.001$ \\
Mean post-prandial $^{\mathrm{d}}$ & $7.3 \pm 1.6$ & $8.1 \pm 1.6$ & $<0.02$ \\
Daily $^{\mathrm{e}}$ & $6.6 \pm 1.4$ & $6.7 \pm 1.2$ & $\mathrm{NS}$ \\
$\mathrm{HbA}_{\text {ic }}(\%)$ & $8.3 \pm 1.3$ & $8.3 \pm 1.4$ & $\mathrm{NS}$ \\
\hline
\end{tabular}

Results expressed as mean $\pm \mathrm{SD}$; NS = not significant

${ }^{a}$ Mean of 03.00, 05.00, 07.00 h samples; ${ }^{b}$ Mean of samples $2 \mathrm{~h}$ after each main meal; ${ }^{c}$ Difference between pre-prandial and $2 \mathrm{~h}$ postprandial (mean of three values); ${ }^{\mathrm{d}}$ Time-averaged mean for $2 \mathrm{~h}$ after

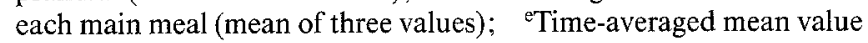
for whole $24 \mathrm{~h}$ same times. Patients were seen by an experienced dietitian (SL) at the start of the study for detailed explanation of the diets, and then at least fortnightly for discussion of problems and to check their weight. Further details of the protocol and 24-h profiles are given elsewhere [3].

\section{Laboratory Methods}

Plasma glucoses were estimated by a glucose oxidase method (Boehringer, Mannheim, GOD-Perid) and insulin by radioimmunoassay using charcoal adsorption [12]. Coefficient of variation for this assay was $17 \%$, with a sensitivity of $2.5 \mathrm{mU} / 1$. Plasma total cholesterol was measured by the Liebermann-Burchard method [13], and lipoprotein fractions by precipitation techniques [14]. Plasma triglycerides were measured by enzymatic hydrolysis [15] and $\mathrm{HBA}_{1 \mathrm{c}}$ percentage estimated by an isoelectric focussing technique[16], the normal range for this laboratory being $5 \%-8 \%$, and coefficient of variation for the assay $9 \%$. Statistics were analysed by Student's paired t-test, the insulin and triglyceride data having been log-transformed.

\section{Results}

The mean plasma glucoses during the two profiles are shown in Figure 1. These were analysed in various ways (Table 2). The 2-h post-prandial glucose (mean of samples taken $2 \mathrm{~h}$ after each main meal) was $8.7 \mathrm{mmol} / 1$ on the high carbohydrate diet and $7.3 \mathrm{mmol} / \mathrm{l}$ on the low carbohydrate diet $(p<0.01)$. Mean incremental glucose (mean for the three meals of the difference between preprandial and 2-h post-prandial values) was $2.8 \mathrm{mmol} / 1$ on the high carbohydrate and $1.4 \mathrm{mmol} / 1$ on the low carbohydrate diet $(p<0.001)$. The time-averaged mean glucose value for the whole $2 \mathrm{~h}$ after each meal (mean of three meals) was $8.1 \mathrm{mmol} / 1$ on the high carbohydrate and $7.3 \mathrm{mmol} / \mathrm{l}$ on the low carbohydrate diet $(p<0.02)$. Post-prandial glycaemia was thus significantly greater on the high carbohydrate diet, when assessed in various ways. By contrast, the mean basal plasma glucose (mean of samples at $03.00,05.00$ and $07.00 \mathrm{~h}$ ) was $5.3 \mathrm{mmol} / 1$ on the high carbohydrate and $5.9 \mathrm{mmol} / 1$ on the low carbohydrate diet $(p<0.05)$. Time-averaged mean plasma

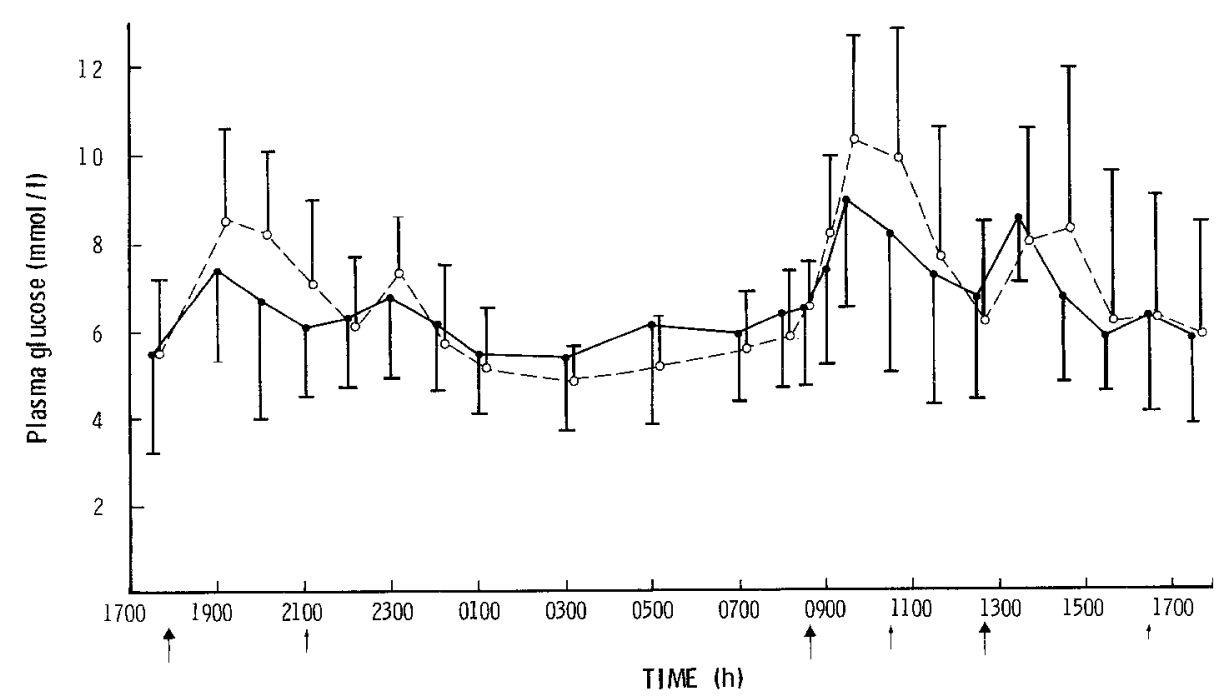

Fig. 1. Mean $( \pm$ SD) plasma glucose levels of patients during their high carbohydrate $\left(\mathrm{O}_{-} \ldots \mathrm{O}\right)$ and low carbohydrate $(-) 24 \mathrm{~h}$ profiles. $\uparrow$ denotes a meal and $\uparrow$ a snack 

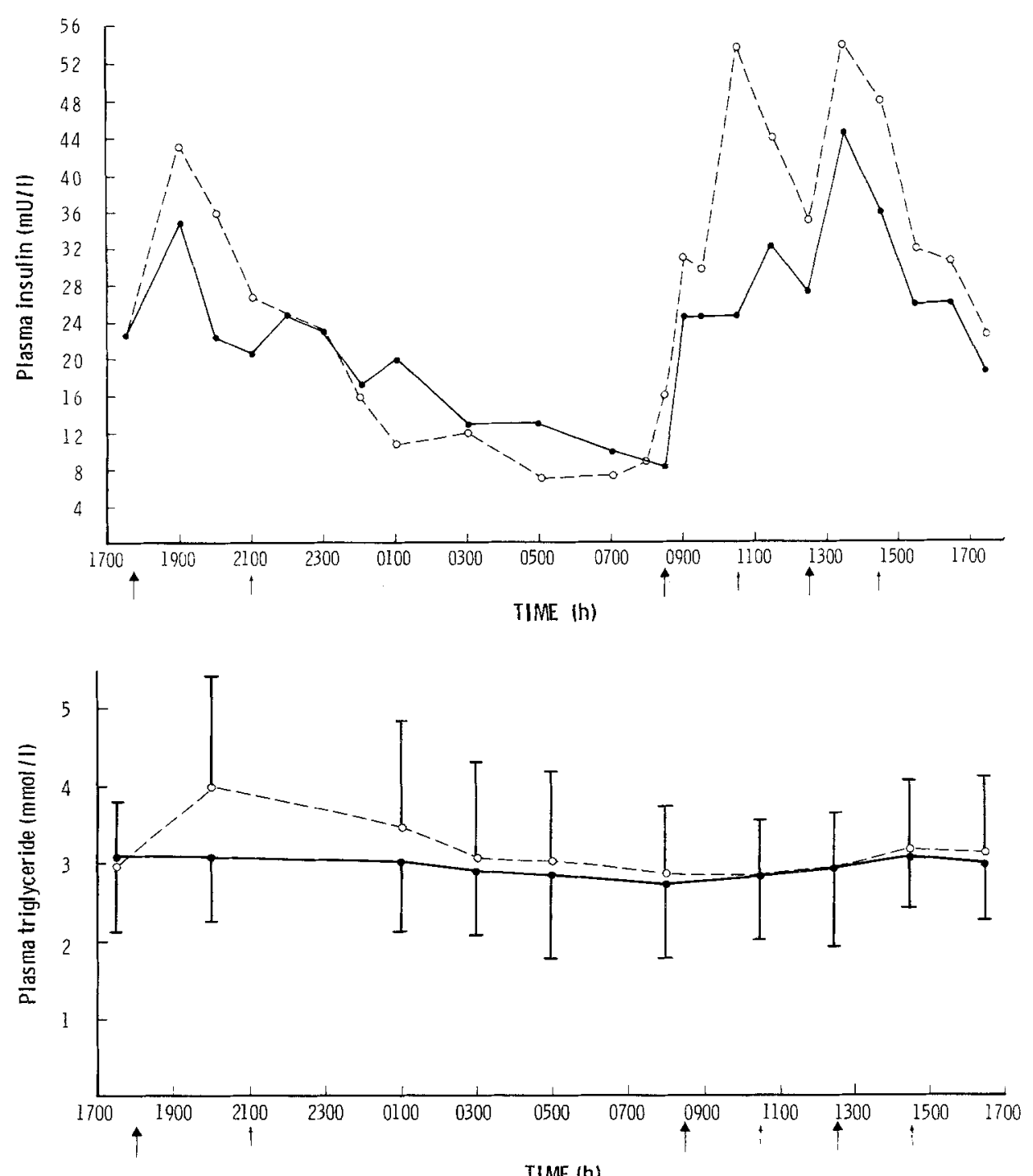

Fig. 2. Mean plasma insulin levels of patients during their high carbohydrate $\left(\mathrm{O}-\mathrm{-}_{--\mathrm{O}}\right)$ and low carbohydrate (-) $24 \mathrm{~h}$ profiles. $\uparrow$ denotes a meal and $\uparrow$ a snack
Fig. 3. Mean ( \pm SD) plasma triglyceride levels of patients during their high carbohydrate $\left(\mathrm{O}_{--}--\mathrm{O}\right)$ and low carbohydrate $(-) 24 \mathrm{~h}$ profiles. $\uparrow$ denotes a meal and $\uparrow$ a snack

Table 3. Total plasma cholesterol and lipoprotein cholesterol subfractions on low carbohydrate and high carbohydrate diets

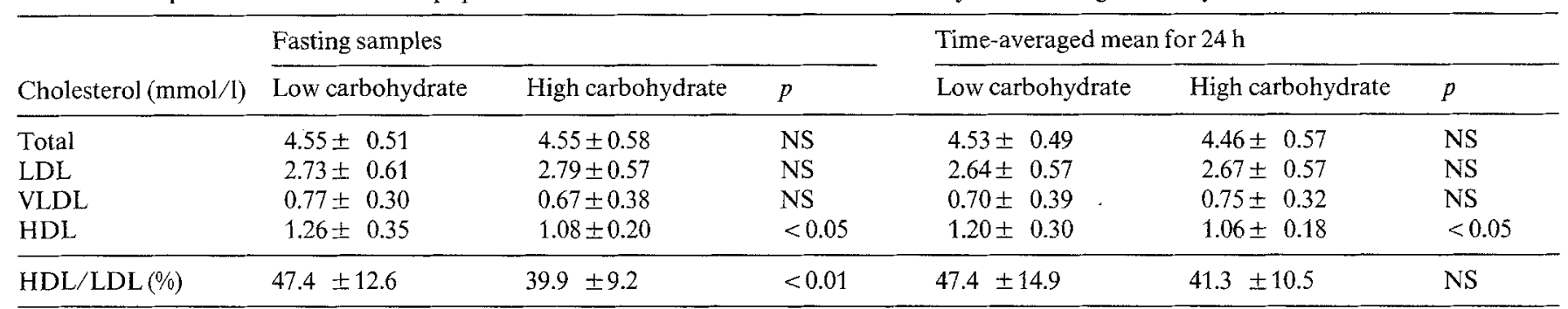

Results expressed as mean $\pm \mathrm{SD}$; NS = not significant

glucose for the whole $24 \mathrm{~h}$ was $6.7 \mathrm{mmol} / \mathrm{l}$ on the high carbohydrate and $6.6 \mathrm{mmol} / 1$ on the low carbohydrate $\operatorname{diet}(p=\mathrm{NS})$.

Mean plasma insulin for the $24 \mathrm{~h}$ (Fig. 2) was $26.8 \pm$ 29.5 (SD) $\mathrm{mU} / 1$ on the high carbohydrate and $22.4 \pm$ $26.2 \mathrm{mU} / 1$ on the low carbohydrate $\operatorname{diet}(p=\mathrm{NS})$. Mean insulin for $2 \mathrm{~h}$ after each main meal was $41.7 \pm$ $51.8 \mathrm{mU} / 1$ on the high carbohydrate and $30.9 \pm$
$28.6 \mathrm{mU} / 1$ on the low carbohydrate $\operatorname{diet}(p=\mathrm{NS})$. Mean basal insulin (mean of samples at 03.00, 05.00 and $07.00 \mathrm{~h}$ ) was $9.2 \pm 8.7 \mathrm{mU} / 1$ on the high carbohydrate and $12.2 \pm 18.4 \mathrm{mU} / 1$ on the low carbohydrate $\operatorname{diet}(p=$ NS).

Mean plasma total cholesterol levels (Table 3) were not significantly different at any of the ten time points at which samples were obtained, fasting levels being iden- 
tical at $4.55 \mathrm{mmol} / 1$. Low density lipoprotein (LDL) and very low density lipoprotein (VLDL) fractions were also similar. High density lipoprotein (HDL) cholesterol was higher on the low carbohydrate diet, time-averaged mean value for the $24 \mathrm{~h}$ being $1.06 \mathrm{mmol} / 1$ on the high carbohydrate and $1.20 \mathrm{mmol} / 1$ on the low carbohydrate diet $(p<0.05)$. The fasting HDL/LDL ratio was also significantly higher on the low carbohydrate diet, but the mean HDL/LDL ratio for the whole $24 \mathrm{~h}$ was not significantly different on the two diets. Mean fasting plasma triglyceride levels (Fig.3) were $2.83 \mathrm{mmol} / 1$ on the high carbohydrate and $2.55 \mathrm{mmol} / 1$ on the low carbohydrate diet (NS) and the mean values over the $24 \mathrm{~h}$ were 3.25 and $2.97 \mathrm{mmol} / 1$ respectively (NS). Four of the ten patients were found to have Type IV hyperlipoproteinaemia.

$\mathrm{HbA}_{1 \mathrm{c}}$ was $8.3 \%$ on both diets. Mean body weights were $76.8 \mathrm{~kg}$ on the high carbohydrate and $77.0 \mathrm{~kg}$ on the low carbohydrate diet (NS). Drug therapy was not changed in any patient throughout the study.

\section{Discussion}

Carbohydrate restriction is still advised in the majority of diabetic clinics in the UK [17], but there is no clear evidence that this leads to improved carbohydrate tolerance unless total calories are also restricted. For example, one study [18] showed that six out of nine obese Type 2 diabetic patients achieved significant improvement of carbohydrate tolerance according to predefined criteria while on a low carbohydrate, weight-reducing diet, but only three out of 26 non-obese patients improved on the same diet. Diets rich in carbohydrate and fibre, however, have been shown to benefit Type 1 [1-3] and Type 2[3, 4, 19] diabetic patients, without the need for calorie restriction. The mechanisms involved have not been fully elucidated but certain types of fibre have been shown to reduce post-prandial glycaemia $[9,20]$, and reduce the rate of carbohydrate absorption [6, 20,21]. Furthermore, one crossover study [10], comparing two diets with identical amounts of carbohydrate, fat and protein but differing in fibre content, showed clear reduction of glucose levels throughout the day on the high fibre diet, but no reduction of fasting levels. By contrast, Brunzell et al. [11] showed that the fasting glucose levels of treated diabetic patients were lower on an $85 \%$ carbohydrate diet than on one containing $45 \%$ of total calories in carbohydrate form; this was despite all the carbohydrate being supplied as simple sugars, and neither diet containing any fibre at all.

These results suggest two separate mechanisms for fibre and digestible carbohydrate, the former affecting post-prandial glycaemia, and the latter altering basal glucose levels. The present study provides support for this suggestion. The control diet was low in both carbohydrate and fibre, and the test diet was rich in digestible carbohydrate but low in fibre, total calories remaining the same. Thus, any differences between them must be due to the different carbohydrate (or possibly fat) content, and not the fibre. The most important finding is the small but statistically significant reduction in basal plasma glucose on the high carbohydrate diet. Although by itself of little clinical significance, this finding suggests that digestible carbohydrate does indeed have an effect independent of fibre. Basal plasma insulins did not rise on the high carbohydrate diet, suggesting that increased insulin sensitivity might explain this finding, possibly by an effect on insulin receptors [22]. Not surprisingly, plasma glucose levels were higher after meals on the high carbohydrate diet, but despite this average glucose levels throughout the $24 \mathrm{~h}$ and $\mathrm{HbA}_{1 \mathrm{c}}$ percentages were almost identical on the two diets.

Despite the substantial differences in the amount of carbohydrate of the two diets, the only clear effects on lipid metabolism were the higher absolute HDL level and the higher fasting HDL/LDL ratio on the low carbohydrate diet. Rivellese et al. [2] found HDL levels to be higher in diabetics after 10 days on a low carbohydrate diet than after a similar period on a high carbohydrate, high fibre diet; HDL/LDL ratios were not measured. One study [3] showed a higher mean HDL/LDL ratio in Type 2 diabetic patients on a high carbohydrate, high fibre diet than on a low carbohydrate diet; Type 1 diabetic patients, however, had higher absolute levels of HDL on the low carbohydrate diet, although the HDL/LDL ratio was the same on the two diets. Results are therefore conflicting and further investigation is needed. There were no significant differences in the plasma triglyceride levels at any time during the $24 \mathrm{~h}$, despite four of the patients having Type IV hyperlipoproteinaemia.

The primary aim of this study was to discover whether the digestible component contributes to the overall improvement in diabetic control which is achieved by a high carbohydrate, high fibre diet. There is no evidence that dietary fibre, when given on its own, can influence fasting glucose levels, and the present findings endorse our earlier conclusions that an optimal diabetic diet should be rich in both dietary fibre and digestible carbohydrate. In all our studies to date the carbohydrate has been mainly in complex form, and we cannot therefore comment on the consequences of including simple sugars in the diabetic diet. Furthermore, all our patients have been well controlled at the start of the study, so these results may not apply to newly diagnosed and poorly controlled diabetic patients. Any advice concerning the recommended composition of a diabetic diet must always be coupled to the reminder that in the overweight patient calorie restriction remains the most important dietary goal.

Acknowledgements. We thank the volunteers for their participation, Dr. T.D.R. Hockaday for allowing access to patients, Mrs. E. Cassels for nursing assistance, the British Diabetic Association, the Simon Broome Heart Research Trust, the Flora Information Service, Mars Ltd. and The Sugar Association for their financial support and Mrs. A. Reeve and Miss P. Ogden for secretarial assistance. 


\section{References}

1. Simpson RW, Mann JI, Eaton J, Carter RD, Hockaday TDR (1979) High carbohydrate diets and insulin-dependent diabetics. Br Med J 2: 523-525

2. Rivellese A, Riccardi G, Giacco A, Pacioni D, Genovese S, Mattioli PL, Mancini M (1980) Effect of dietary fibre on glucose control and serum lipoproteins in diabetic patients. Lancet $2: 447-450$

3. Simpson HCR, Lousley S, Geekie M, Simpson RW, Carter RD, Hockaday TDR, Mann JI (1981) A high carbohydrate leguminous fibre diet improves all aspects of diabetic control. Lancet 1:1-5

4. Simpson RW, Mann JI, Eaton J, Moore RA, Carter RD, Hockaday TDR (1979) Improved glucose control in maturity onset diabetes treated with high carbohydrate-modified fat diet. $\mathrm{Br}$ Med $\mathrm{J} 1$ : 1753-1756

5. Jenkins DJA, Wolever TMS, Nineham R, Taylor R, Metz GL, Bacon S, Hockaday TDR (1978) Guar crispbread in the diabetic diet. Br Med J 2: 1744-1746

6. Holt S, Heading RC, Carter DC, Prescott LF, Tothill P(1976) Effect of gel fibre on gastric emptying and absorption of glucose and paracetamol. Lancet 1:636-639

7. Morgan LM, Goulder TJ, Tsioladis D, Marks V, Alberti KGMM (1979) The effect of unabsorbable carbohydrate on gut hormones: Modification of post-prandial GIP secretion by guar. Diabetologia $17: 85-89$

8. Pederson O, Hjøllund E, Lindskow HO, Schwartz Sørensen N (1980) Increased insulin receptors on monocytes from insulin-dependent diabetics after a high-starch, high fibre diet. Diabetologia 19:306 (Abstract)

9. Jenkins DJA, Wolever TMS, Hockaday TDR, Leeds AR, Howarth R, Bacon S, Apling EC, Dilawari J (1977) Treatment of diabetes with guar gum. Lancet 2: 779-780

10. Miranda PM, Horwitz DL (1978) High fibre diets in the treatment of diabetes mellitus. Ann Intern Med 88: 482-486

11. Brunzell JD, Lerner RL, Porte D, Bierman EL (1973) Effect of a fat free, high carbohydrate diet on diabetic subjects with fasting hyperglycemia. Diabetes 23: 138-142

12. Albano JDM, Ekins RP, Maritz G, Turner RC(1972) Sensitive, precise radioimmunoassay of serum insulin relying on charcoal separation of bound and free hormone moieties. Acta Endocrinol 70: 487-509
13. Haung TC, Chen CP, Wefler V, Rafter A (1961) A stable reagent for the Liebermann-Burchard reaction. Anal Chem 33:1405-1407

14. Ononga IC, Lewis B (1976) Lipoprotein fractionation by a precipitation method - A simple quantitative procedure. Clin Chim Acta $71: 397-402$

15. Eggstein M, Kreutz FH (1966) Eine neue Bestimmung der Neutralfette im Blutserum und Gewebe. Klin Wschr 44:262-267

16. Jeppson JD, Franzen B, Gaal AB (1980) Simplified determination of haemoglobin $A_{1}$ in diabetic patients by use of electrofocussing. In: Radola BJ (ed) Electrophoresis 1979 advanced methods. Walter de Gryter, Berlin New York, pp 656-661

17. Truswell AS, Thomas BI, Brown AM (1975) Survey of dietary policy and management in British diabetic clinics. Br Med J 2: 7-11

18. Perkins JR, West TET, Sonksen PH, Lowy C, Iles C (1977) The effects of energy and carbohydrate restriction in patients with chronic diabetes mellitus. Diabetologia 13:607-614

19. Anderson JW, Ward K (1978) Long-term effects of high-carbohydrate, high-fiber diets in glucose and lipid metabolism: a preliminary report on patients with diabetes. Diabetes Care 1:77-82

20. Jenkins DJA, Wolever TMS, Leeds AR, Gassull MA, Haisman $\mathbf{P}$, Dilawari J, Goff DV, Metz GL, Alberti KGMM (1978) Dietary fibres, fibre analogues and glucose tolerance - Importance of viscosity. Br Med J 1: 1392-1394

21. Elsenhans B, Süfke U, Blume R, Caspary WF (1980) The influence of carbohydrate gelling agents on rat intestinal transport of monosaccharides and neutral amino acids in vitro. Clin Sci 59:373-80

22. Ward GM, Simpson RW, Simpson HCR, Naylor BA, Mann JI, Turner RC (1982) Insulin receptor binding increased by high carbohydrate diet in non insulin-dependent diabetics. Europ J Clin Invest 12 : (in press)

Received: 25 August 1981

and in revised form: 6 May 1982

Dr. J.I. Mann

Diabetes Research Laboratories

Radcliffe Infirmary

Woodstock Road

Oxford $0 \times 26 \mathrm{HE}, \mathrm{UK}$ 